\title{
Characteristics of juvenile survivors reveal spatio-temporal differences in early life stage survival of Baltic cod
}

\author{
B. Huwer ${ }^{1,2, *}$, H. H. Hinrichsen ${ }^{3}$, U. Böttcher ${ }^{4}$, R. $\operatorname{Voss}^{5}{ }^{5}$ F. Köster ${ }^{1}$ \\ ${ }^{1}$ Technical University of Denmark, National Institute of Aquatic Resources, Charlottenlund Castle, Jægersborg Allé 1, \\ 2920 Charlottenlund, Denmark \\ ${ }^{2}$ Department of Biological Sciences, Marine Ecology, Aarhus University, Ole Worms Allé 1, 8000 Aarhus C, Denmark \\ ${ }^{3}$ Helmholtz Centre for Ocean Research Kiel, GEOMAR, Düsternbrooker Weg 20, 24105 Kiel, Germany \\ ${ }^{4}$ Thünen-Institute of Baltic Sea Fisheries, Alter Hafen Süd, 18069 Rostock, Germany \\ ${ }^{5}$ Sustainable Fisheries, Department of Economics, University of Kiel, Wilhelm-Seelig-Platz 1, 24105 Kiel, Germany
}

\begin{abstract}
The spatio-temporal origin of surviving juvenile Baltic cod Gadus morhua was investigated by coupling age information from otolith microstructure analysis and hydrodynamic modeling, which allowed backtracking of drift routes in time and space. The suitability of hydrodynamic modeling for drift simulations of early life stages of Baltic cod up to the pelagic juvenile stage was validated by comparing model simulations with the catch distribution from a survey targeting pelagic juveniles, and mortality rates and hatch date distributions of pelagic and demersal juveniles were estimated. Hatch dates and hatch locations of juvenile survivors showed distinct patterns which did not agree well with the abundance and spatial distribution of eggs, suggesting marked spatio-temporal differences in larval survival. The good agreement of the spatio-temporal origin of survivors from this field investigation with previous modeling studies on the survival chances of early-stage larvae and with general spatio-temporal patterns of larval prey availability suggests that differences in survival are related to food availability during the early larval stage. Results are discussed in relation to the recruitment process of Baltic cod, in particular with respect to the critical period and match-mismatch hypotheses, and to possible implications for the placement of a Marine Protected Area which was established to ensure undisturbed spawning of Baltic cod.
\end{abstract}

KEY WORDS: Recruitment $\cdot$ Critical period hypothesis $\cdot$ Match-mismatch hypothesis $\cdot$ Mortality rate $\cdot$ Hydrodynamic modeling $\cdot$ Otolith $\cdot$ Hatch date $\cdot$ Marine Protected Area $\cdot$ Gadus morhua

\section{INTRODUCTION}

Recruitment variability in marine fishes shows tremendous fluctuations, and it is commonly accepted that this variability is to a considerable extent caused by processes during early life (Houde 1987). A variety of factors act on the vulnerable early life stages, including predation, starvation, diseases, and advection to unsuitable areas (Houde 1987), which has led to various hypotheses on mechanisms shap- ing recruitment dynamics. These include the 'critical period' (Hjort 1914) and 'match-mismatch' (Cushing 1975) hypotheses, which emphasize the need for suitable prey availability to ensure high larval survival.

In the case of the Eastern Baltic stock of Atlantic cod Gadus morhua (hereafter referred to as Baltic cod), strong differences in recruitment success between the early 1980 s, a period of extremely high stock size, and the following decades, are obvious 
(Köster et al. 2005). Oxygen-related egg mortality, caused by lack of formerly regular inflows of oxygenrich water from the North Sea, is a major source of recruitment variability (Vallin et al. 1999, Köster et al. 2001, 2005). However, high numbers of eggs found in ichthyoplankton surveys after a strong inflow event in 1993 and subsequent years did not result in increased larval abundances and recruitment levels (Köster et al. 2005). Furthermore, recent estimates of year-class strength suggest improving recruitment despite apparently unfavorable environmental conditions for egg survival (ICES 2013). A possible explanation for these observations may be variable survival during the larval stage, and there are indeed indications that the early larval phase from hatch to well-established feeder is a critical life stage of Baltic cod (Hinrichsen et al. 2002, Köster et al. 2003) as well as of other cod stocks (e.g. Sundby et al. 1989).

Despite the apparent influence of processes during the larval stage in shaping the recruitment dynamics of Baltic cod, information on larval survival from field studies is scarce (Grønkjær et al. 1997, Grønkjær \& Wieland 1997, Grønkjær \& Schytte 1999, Voss et al. 2001, Huwer et al. 2011) but a series of studies approached the issue of larval survival success with biophysical modeling exercises (Voss et al. 1999, Hinrichsen et al. 2001, 2002, 2003b, 2005, Schmidt \& Hinrichsen 2008). Model results suggested that retention and dispersal of early life stages, especially during the first feeding stage, influence survival success. Larvae hatched during the early part of the spawning season in spring and early summer profited from retention in the spawning area which provided high abundances of suitable prey during this time of the season, whereas later hatched larvae had higher survival chances when dispersed into shallower areas which provided better feeding conditions during the late spawning season. This emphasizes the importance of processes related to the 'critical period' hypothesis (Hjort 1914), suggesting that variable survival rates are due to variations in food availability at the critical stage when the transition from endogenous (yolk) to exogenous (plankton) feeding occurs, as well as to the 'match-mismatch' hypothesis (Cushing 1975).

While Cushing's (1975) original match-mismatch hypothesis mainly focused on a temporal overlap of predator and prey, a spatial overlap is also necessary for a 'match.' The importance of both spatial and temporal aspects for a match or mismatch situation cannot be stressed enough in the case of Baltic cod, as the cod spawning grounds in the Baltic show a high degree of environmental heterogeneity (Hin- richsen et al. 2007), and Baltic cod express an extremely protracted spawning season with shifts in peak spawning times (Wieland et al. 2000). Especially the spatio-temporal match of abundances of Pseudocalanus acuspes nauplii, the preferred prey item of larval Baltic cod (Voss et al. 2003), with larvae in the critical first feeding stage is likely a necessary prerequisite for high larval survival. Due to a lack of inflow events and the associated decreases in salinity, standing stocks of $P$. acuspes were drastically reduced in the past decades (Möllmann et al. 2000). A biophysical modeling study by Hinrichsen et al. (2002) suggested that first-feeding larvae of Baltic cod during this period have indeed changed from a non-limited to a food-limited stage. In simulations considering a prey field without $P$. acuspes as prey items, larvae that hatched late in the spawning season and at the edges of the spawning ground in the Bornholm Basin had considerably higher survival chances due to a higher spatio-temporal overlap with nauplii of Acartia spp. and Temora longicornis. A similar result was found in a more recent modeling study (Hinrichsen et al. 2005) based on spatial overlap patterns of larvae and their prey.

Gallego et al. (2007) pointed out recent advances in modeling physical-biological interactions during the early life history of fish, but also emphasized the increasing need for validation of coupled biophysical models. Thus, the aim of the present study was to test the results from bio-physical model simulations in a field setting by investigating the temporal and spatial origin of juvenile Baltic cod caught in field surveys. Moreover, the applicability of the hydrodynamic model in use to reliably simulate drift patterns up to the pelagic juvenile stage was evaluated by comparing drift simulations with the catch distribution of juvenile fish from the field sampling. The approach used is based on a characteristics-of-survivors analysis (Rice et al. 1987, Taggart \& Frank 1990), which has gained increasing interest as a tool to investigate recruitment processes. The basic idea of this approach is that survivors are not a random subset of the offspring, but have emerged through selective sources of mortality related to the inter-individual variability of certain characteristics. The vast majority of studies have examined survivor characteristics in terms of growth and/or temporal origin (e.g. Rice et al. 1987, Limburg et al. 1999, Baumann et al. 2008), including investigations on cod (Meekan \& Fortier 1996, Nielsen \& Munk 2004). Only relatively few attempts have been made to relate survivors to their spatial origin (e.g. Marteinsdottir et al. 2000, Irigoien et al. 
2008). The present study focuses on survivor characteristics in terms of the temporal as well as the spatial origin of juveniles. Advances in hydrodynamic modeling allow survivors to be connected to certain areas by backtracking their drift routes (Gallego et al. 2007). Here we coupled juvenile age information from analyses of otolith microstructure and hydrodynamic modeling, aiming to track fish

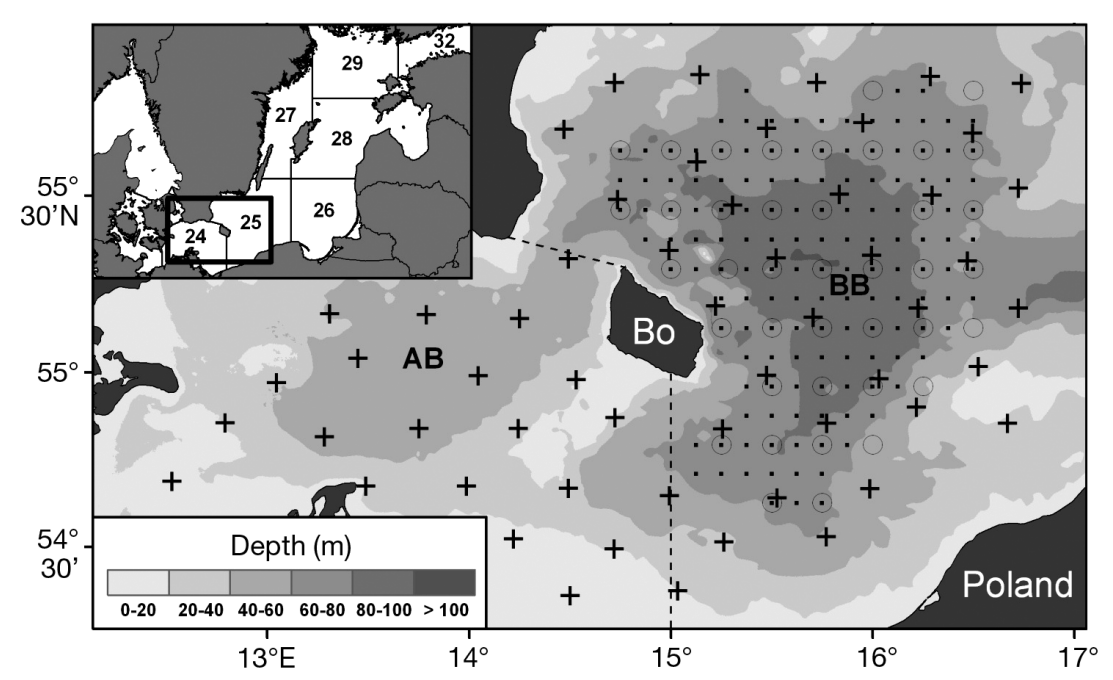

Fig. 1. Study area in the Baltic Sea. Inset: Overview of the southern Baltic Sea including ICES Subdivisions (numbers and thin black lines) and location of the detailed main map (boxed area). Main map: Sampling stations for pelagic juvenile cod in November 2000 (crosses, Isaacs-Kidd midwater trawl) and ichthyoplankton in April to August 2000 (circles, Bongo net). The black dots depict the initial seeding positions for larval drifters in the hydrodynamic model. Bo: Bornholm Island; BB: Bornholm Basin; AB: Arkona Basin. Dashed lines: border between ICES Sub-divisions 24 and 25

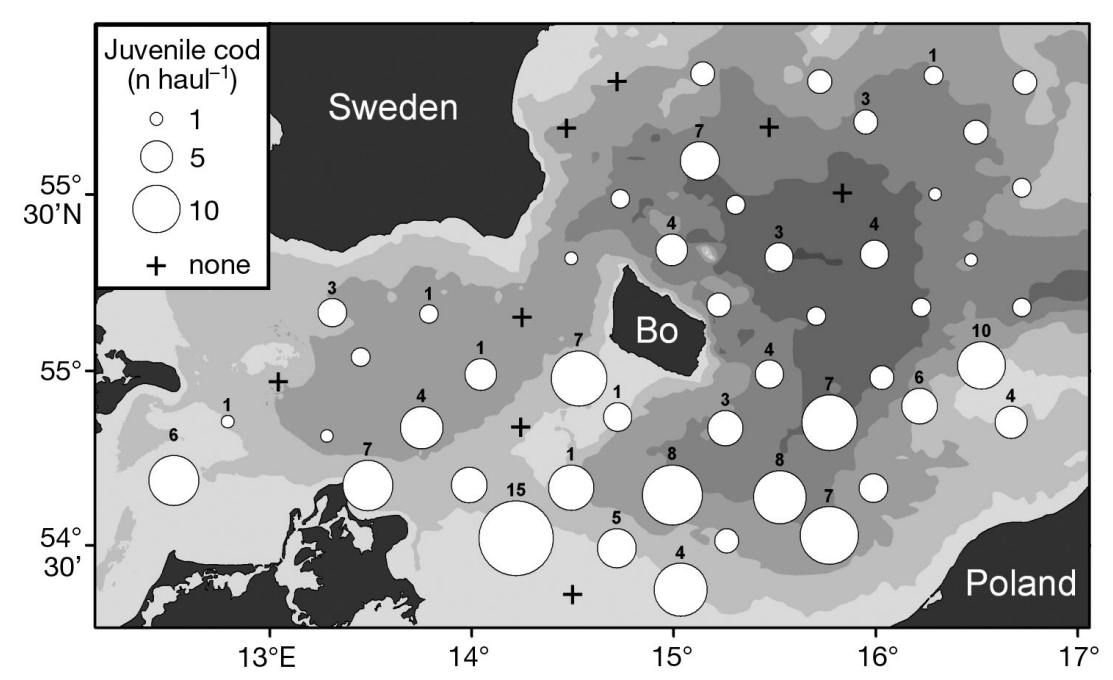

Fig. 2. Catch distribution of pelagic juvenile cod Gadus morhua in November 2000. The size of the white circles indicates the number of juvenile cod per haul (numbers above circles denote the numbers of juveniles selected for ageing by otolith analysis). Bo: Bornholm Island that had survived up to the juvenile stage back to their spatio-temporal hatch origin.

Specifically, we investigated (1) the degree of overlap between simulated and observed distributions of juveniles, (2) the temporal origin of juvenile survivors, and (3) the spatial origin of juvenile survivors. Hatch origins of survivors in the Bornholm Basin, at present the only spawning ground regularly sustaining successful egg development (Köster et al. 2005), and the area where the main biomass of the stock is concentrated (Eero et al. 2012), are related to spawning effort and egg survival probability as well as to results from previous biophysical modeling studies, the availability of suitable larval prey, and ambient temperatures. Results are discussed in relation to the recruitment process of Baltic cod, in particular with respect to the critical period and match-mismatch hypotheses, and to possible implications for the placement of a Marine Protected Area (MPA) in the Bornholm Basin, which was established in the mid-1990s to ensure undisturbed spawning of Baltic cod (ICES 2004).

\section{MATERIALS AND METHODS}

\section{Sampling procedure and laboratory analyses of ichthyoplankton and pelagic juveniles}

From 26 October to 11 November 2000, a total of 268 pelagic juvenile cod were sampled with an IsaacsKidd midwater trawl in the southern Baltic Sea (Figs. 1 \& 2). Samples were immediately frozen at $-20^{\circ} \mathrm{C}$ for later investigation in the laboratory.

To investigate the horizontal distribution and abundance of ichthyoplankton in the Bornholm Basin, Bongo net samples were collected in April, May, July, and August 2000. Double oblique hauls (ship speed: 3 knots) were conducted on a station grid with a regular spacing of approximately 10 nautical miles (n miles) (Fig. 1). The 2 Bongo nets $(60 \mathrm{~cm}$ diameter each) were equipped with 
mesh sizes of 335 and $500 \mu \mathrm{m}$ and with flowmeters to determine the volume of filtered water. The samples were preserved in $4 \%$ buffered formaldehyde/seawater solution. To obtain vertical profiles of the ambient environment, CTD casts were conducted at the sampling stations.

In the laboratory, standard length (SL), total length (TL), and wet weight of the pelagic juveniles were determined. Ichthyoplankton samples from the $335 \mu \mathrm{m}$ Bongo nets were analyzed under a stereo microscope. Cod eggs were sorted from the samples, counted, and staged. A subsample of at least 100 specimens was processed for staging using a 4-stage system based on morphological criteria (for details, see Wieland et al. 2000) with stages Ia and Ib combined. The counts were finally standardized to $1 \mathrm{~m}^{2}$ sea surface by the volume of filtered water and the maximum depth of the tow $(\sim 2 \mathrm{~m}$ above the seabed).

\section{Otolith analyses and determination of ages, hatch dates, and mortality rates}

The back-calculation approach used in the present study is dependent on reliable age estimates. The daily nature of increment formation has been validated for cod (e.g. Campana 1989), including the stock in the Baltic (Clemmesen \& Doan 1996), and daily increment deposition begins on the day of hatch. Thus, enumeration of growth increments in Baltic cod otoliths provides reliable estimates of ages and hatch dates.

A subsample of pelagic juveniles was chosen for otolith age determinations to be used for the backcalculation of hatch dates and positions. This subsample $(\mathrm{n}=135)$ was chosen in such a manner that the entire sampling area was covered (Fig. 2) and that the length distribution of the subsample resembled the length distribution of all available samples (Fig. 3). Sagittal otoliths of pelagic juveniles were removed, mounted on glass slides with thermoplastic cement, and ground from both sides with different grades of lapping film (12 to $0.05 \mu \mathrm{m}$ ). Growth increments on the otoliths were enumerated to determine the age of the fish. To resolve the fine innermost growth increments from the otolith core to the begin-

ning of the secondary primordia, those primary increments were viewed at a magnification of 1512x. For the wider secondary growth increments, lower magnifications (480-960×) were sufficient.

Hatch dates of pelagic juveniles in the subsample were calculated by subtracting the age in days of each fish from the day of capture. The survey conducted in November 2000 was targeted at pelagic juveniles. However, at this time of the year, some of the 0 -group cod have already made the transition to a demersal life stage (Hüssy et al. 1997, Hinrichsen et al. 2003a). Thus, in order to evaluate the temporal origin of survivors, these demersal juveniles need to be considered as well. Unfortunately, no otolith samples for demersal juveniles were available for the year 2000. However, length distribution data for demersal 0-group cod caught in November 2000 during the Baltic International Trawl Surveys (BITS) are available from ICES (http://datras.ices.dk/Home/ default.aspx). These length distribution data and an age-SL relationship for demersal juvenile Baltic cod from the literature $\left(\right.$ age $=1.23 \mathrm{SL}+45.93 ; \mathrm{r}^{2}=0.884$; Fey \& Linkowski 2006) were used to estimate the hatch date distribution of demersal juveniles. The length data from ICES were given in $1 \mathrm{~cm}$ classes of $\mathrm{TL}$, while the age-length relationship from Fey \& Linkowski (2006) is based on SL. Thus, the length distribution data from ICES were first converted from $\mathrm{TL}$ to $\mathrm{SL}$, based on a linear relationship obtained from measured TL and SL of pelagic juveniles from the present study $\left(\mathrm{SL}=0.9181 \mathrm{TL}-0.019 ; \mathrm{r}^{2}=0.9978\right.$ ). 
Then, for each length class, a corresponding age class was calculated, resulting in age classes corresponding to $11 \mathrm{~d}$ bins. Hatch dates were determined by subtracting the midpoint of each age class in days from the day of catch, which was defined as the midpoint of the BITS survey (day of year 315). Based on the length class distribution from the survey, fish with a total length of 4 to $12 \mathrm{~cm}$ were considered to belong to the 0 -group. Only data for catch positions in ICES Subdivisions 25 and 26 east of Bornholm were considered, as those fish were assumed to belong to the eastern Baltic cod stock, while catches farther west (Subdivision 24) probably mainly consist of fish belonging to the western stock.

To compensate for the problem of cumulative mortality when estimating true hatch date distributions, the numbers of fish per age class were corrected by the following procedure. First, estimates of the daily instantaneous rate of mortality $(Z)$ were obtained using the age-based catch curve method (Ricker 1975). Juveniles were grouped into age classes, and the natural logarithm of the number of fish in each age class $\left(N_{t}\right)$ was plotted against the midpoint of the corresponding age class $(t)$. Pelagic juveniles were grouped into $5 \mathrm{~d}$ bins. As 1 of the age classes only consisted of a single fish, which would have given the value of $\ln \left(N_{t}\right)=0$, the number of fish in each age class was adjusted to $N_{t}+1$. Age classes of demersal juveniles were defined by the calculated ages from the length distribution, corresponding to age classes in $11 \mathrm{~d}$ bins. Linear regressions were fitted to the data and the slopes $(b)$ were determined, which provide an estimate of $Z$. The most abundant age classes were assumed to be fully recruited for the catch curve analysis, i.e. pelagic juveniles between 71 and $105 \mathrm{~d}$ old and demersal juveniles between 142 and $187 \mathrm{~d}$ old were considered for the mortality estimations.

Adjustments for cumulative mortality were made by raising the number of fish by the equation:

$$
N_{0}=N_{t}\left(\mathrm{e}^{-Z t}\right)^{-1}
$$

where $N_{0}$ is the estimated number at hatching, $N_{t}$ is the number at catch, $Z$ is the instantaneous mortality rate, and $t$ is the age in days.

Cumulative mortality adjusted numbers of pelagic juveniles were needed on an individual level for the determination of back-calculated hatch positions, i.e. $N_{t}=1$ because $N_{0}$ was calculated for each individual fish. The adjusted data were then grouped into $5 \mathrm{~d}$ hatch date bins, summed, and converted into relative numbers (\%). Cumulative mortality adjustments for demersal juveniles were made on the total number of fish per $11 \mathrm{~d}$ hatch date bin and also converted into relative numbers $(\%)$.

For comparison with values of juvenile mortality for other cod stocks from the literature, the percent mortality rate $\left(M, \% \mathrm{~d}^{-1}\right)$ was calculated as:

$$
M=100\left(1-\mathrm{e}^{-Z}\right)
$$

\section{Baltic Sea model and its use in particle tracking}

The hydrodynamic model used in this study is based on the free surface Bryan-Cox-Semtner model (Killworth et al. 1991). A detailed description of the equations and modifications required to adapt the model to the Baltic Sea can be found in Lehmann (1995) and Lehmann \& Hinrichsen (2000b). A detailed analysis of the Baltic Sea circulation has been performed by Lehmann \& Hinrichsen (2000a) and by Lehmann et al. (2002). Physical properties simulated by the hydrodynamic model agree well with known circulation features and observed physical conditions in the Baltic (for further description, see Lehmann 1995, Hinrichsen et al. 1997, Lehmann \& Hinrichsen 2000b). The model domain comprises the entire Baltic Sea including the Gulf of Bothnia, the Gulf of Finland, and the Gulf of Riga, as well as the Belt Sea, the Sound, Kattegat, and Skagerrak. The horizontal resolution is $5 \mathrm{~km}$, with 60 vertical levels specified. The thickness of the different levels was chosen to best account for the different sill depths in the Baltic.

The Baltic Sea model is driven by actual atmospheric data provided by the Swedish Meteorological and Hydrological Institute (Norrköping, Sweden) and river runoff taken from a mean runoff database (Bergstroem \& Carlsson 1994). The meteorological database covers the whole Baltic Sea drainage basin with a grid of $1^{\circ} \times 1^{\circ}$ squares. Meteorological parameters, such as geostrophic wind, $2 \mathrm{~m}$ air temperature, $2 \mathrm{~m}$ relative humidity, surface pressure, cloudiness, and precipitation, are stored with a temporal increment of $3 \mathrm{~h}$. Simulated 3-dimensional velocity fields were extracted (at $6 \mathrm{~h}$ intervals) to develop a data base for a Lagrangian particle tracking exercise on larval cod. This data set offers the possibility to derive Lagrangian drift routes by calculating the advection of 'marked' water particles. Vertical velocities were calculated from the divergence of the horizontal velocity fields. The drifters were allowed to leave the layers where they were launched. The positions of the drifters varied over time as a result of the 3-dimensional velocities that they experienced. For the application in the present study, the model was explicitly run for the year 2000. 
To establish a Lagrangian view of the simulated circulation, drifters can be placed in the modeled flow fields at every location within the model domain. Moreover, the initial launch positions can be chosen independently of the vertical resolution of the model's grid. Simulated drift routes were obtained from Eulerian flow fields by use of a Lagrangian particle tracking technique. The 3-dimensional trajectories of the simulated drifters were computed using a fourth-order Runge-Kutta scheme (Hinrichsen et al. 1997).

\section{Comparison of pelagic juvenile catch distribution with seasonal larval drift patterns}

The hydrodynamic model on Baltic cod larval drift was utilized to investigate larval distribution and transport patterns during the cod spawning season 2000 in order to consider the seasonal variability in larval transports depending on the time of spawning. Lagrangian drifters were released on a regular spaced grid enclosed by the $60 \mathrm{~m}$ isobath encompassing the main spawning area in the Bornholm Basin (Fig. 1). In total, 720 drifters were released at 5 depths between 25 and $35 \mathrm{~m}$, as the majority of feeding Baltic cod larvae occur at these depths after having conducted an ontogenetic vertical feeding migration (Grønkjær et al. 1997, Grønkjær \& Wieland 1997). The grid for drifter release (Fig. 1) consisted of 144 stations (144 stations $\times 5$ depths $=$ 720 drifters). Drifters were inserted into the modeled flow fields at $10 \mathrm{~d}$ intervals and tracked for $70 \mathrm{~d}$, as the mean age of the sampled pelagic juveniles was found to be $72 \mathrm{~d}$ (see Results). The release dates ranged from 1 April to 20 September, thereby encompassing the historical as well as the present main spawning period of Baltic cod (Wieland et al. 2000). A detailed description of these model runs can be found in Hinrichsen et al. (2003b). A recent study by Petereit et al. (2014), using the same hydrodynamic model, did explicitly address the issue of horizontal diffusion and its influence on final drift destinations in the Baltic Sea. Model sensitivity experiments to evaluate the influence of horizontal diffusion on the final distribution of drifters did not reveal any significant deviations from the results of a reference run (i.e. particle transport without any addition of fluctuating velocity components). Based on this sensitivity study, diffusion was not considered in the present study.

In order to obtain an integrated view of drifter end positions after $70 \mathrm{~d}$ of drift, the area of the Baltic Sea was divided into a grid of rectangles by sub-dividing the ICES statistical rectangles into 4 smaller rectangles, thus creating rectangles of approximately $15 \times$ $15 \mathrm{n}$ miles. In this way the share of the 720 initially released drifters that ended in a certain rectangle after $70 \mathrm{~d}$ of drift could be determined, and this value was assigned to the position in the center of each rectangle. This information was used to create distribution maps of simulated residence probability of drifter positions after $70 \mathrm{~d}$. These simulation results were also compared with the catch distribution of pelagic juveniles by calculating an overlap coefficient to quantify the closeness of agreement between simulated and observed distributions. This coefficient $C$ (Horn 1966) is 0 when there is no overlap and 1 at concurrent distributions:

$$
C=2\left(\sum_{i=1}^{n} A_{i} B_{i}\right)\left(\sum_{i=1}^{n} A_{i}^{2}+\sum_{i=1}^{n} B_{i}^{2}\right)^{-1}
$$

where $\mathrm{n}$ is the number of strata (in this case the number of rectangles), and $A$ and $B$ are the relative abundances of simulated drifters and pelagic juveniles caught within each stratum. Only rectangles where survey hauls were conducted were considered in this analysis, and in cases where more than 1 haul was conducted within a rectangle, an effort adjustment was applied by calculating the average number of juveniles caught within the respective rectangles.

\section{Back-calculation of hatch locations}

The model runs described in the previous section proved to be sufficient to simulate the general distribution of larvae and pelagic juveniles (see 'Results'). However, in order to determine the hatching locations of the aged subsample of pelagic juveniles, a higher temporal match between model start dates and juvenile hatch dates as well as end dates of model runs and juvenile catch dates was needed. Thus, another set of model runs was conducted. These model runs utilized the same grid of drifter release positions (see previous subsection and Fig. 1), but the release dates and drift durations were based on the actual ages of the pelagic juveniles. Back-calculated hatch dates from otolith analyses were used to define $5 \mathrm{~d}$ periods of particle release, while the duration of the model runs was determined by the day of juvenile catch. Back-tracked hatch locations were estimated by establishing a database of particle age and location 
and by then determining those drifters in the database that were closest to individual juvenile catch positions at the time of catch. To account for variations of drift routes, the 3 drifters closest to each juvenile catch position were used. In order to obtain an integrated view of the hatch locations of survivors, the study area was divided into a grid of small rectangles by sub-dividing the ICES statistical rectangles into 36 smaller rectangles, thus creating a set of rectangles with a high geographical resolution of approximately $5 \times 5 \mathrm{n}$ miles. The number of back-calculated survivor hatch locations within each of these rectangles was determined. In order to account for the effect of cumulative mortality, the numbers of pelagic juveniles were adjusted on individual level, i.e. $N_{t}=1$ because $N_{0}$ was calculated for each individual fish (see also description of cumulative mortality correction above). The adjusted data were then summed for each rectangle and converted into relative numbers (\%). In order to plot a map of survivor hatch locations, these values were assigned to the position in the center of each rectangle.

\section{Determination of reproductive volume and oxygen-related egg survival}

In contrast to other cod stocks, eggs from the Baltic cod stock do not float in the surface waters, but attain neutral buoyancy and peak abundances in the region of the permanent halocline, i.e. usually at depths below $50 \mathrm{~m}$ (Wieland \& Jarre-Teichmann 1997). Salinities $>11$ psu, oxygen contents $>2 \mathrm{ml} \mathrm{l}^{-1}$, and temperatures $>1.5^{\circ} \mathrm{C}$ form the basis for the calculation of the so-called reproductive volume (RV), i.e. the volume of water that meets minimum environmental requirements for successful cod egg development (Plikshs et al. 1993, Vallin et al. 1999). However, these estimates do not directly consider the environmental conditions inside the water volume that principally sustain egg development. Oxygen concentrations above the threshold level of $2 \mathrm{ml} \mathrm{l}^{-1}$ used to define the RV have a strong positive impact on egg survival (Rohlf 1999), and a sigmoidal oxygen-egg survival relationship can be applied to estimate the fraction of the egg production that will probably survive to the larval stage. Therefore, an index of oxygenrelated egg survival (OES) has been developed (Köster et al. 2005), which incorporates not only the volume for potentially sustaining egg development, but provides a measure of the oxygen condi- tions within the salinity range over which cod eggs are neutrally buoyant.

The hydrographic data which provide the basis for the calculation of RV and OES were obtained at the ichthyoplankton sampling stations (Fig. 1). Physical parameters (conductivity, temperature, and oxygen) of the water column were measured with $\mathrm{CTD} / \mathrm{O}_{2}$ systems. Based on these measurements, we constructed maps of RV and OES by interpolating observed data onto a regular horizontal grid. This procedure was detailed by Hinrichsen et al. (2007).

\section{RESULTS}

\section{Size and age of pelagic juveniles}

The length range (SL: 15.06-57.11 mm, TL: $16.35-62.21 \mathrm{~mm}$ ) of the aged subsample of juveniles covered that of the entire sample. Correspondingly, the average lengths of the entire sample and the aged subsample were 31.94 and $31.76 \mathrm{~mm}$ (SL) and 34.84 and $34.68 \mathrm{~mm}$ (TL), respectively (Fig. 3). The wet weight range was 0.0176 to $1.7452 \mathrm{~g}$, and the average wet weights for the entire and the subsample were 0.3345 and $0.3573 \mathrm{~g}$, respectively. The age range of the subsample was 42 to $105 \mathrm{~d}$, with an average of $71 \mathrm{~d}$. The otolith age readings from the juvenile subsample were used to establish an age vs. SL relationship (Fig. 4). The ages of pelagic juveniles from the entire sample, which were obtained according to this age-SL relationship, ranged from 52 to $101 \mathrm{~d}$ with an average of $72 \mathrm{~d}$.

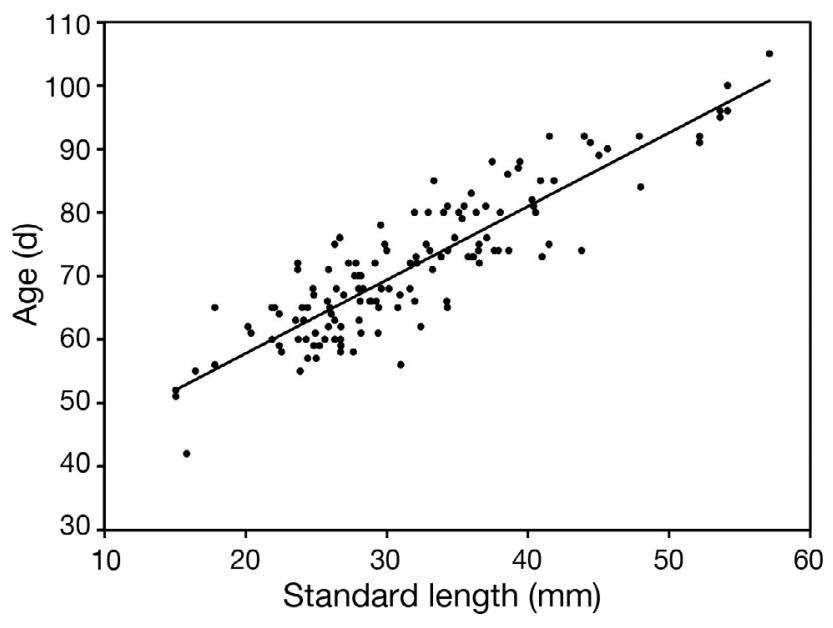

Fig. 4. Age vs. standard length (SL) of pelagic juvenile Baltic cod Gadus morhua $(\mathrm{n}=135)$. Linear regression equation: Age $=1.16 \mathrm{SL}+34.63\left(\mathrm{r}^{2}=0.79\right)$ 

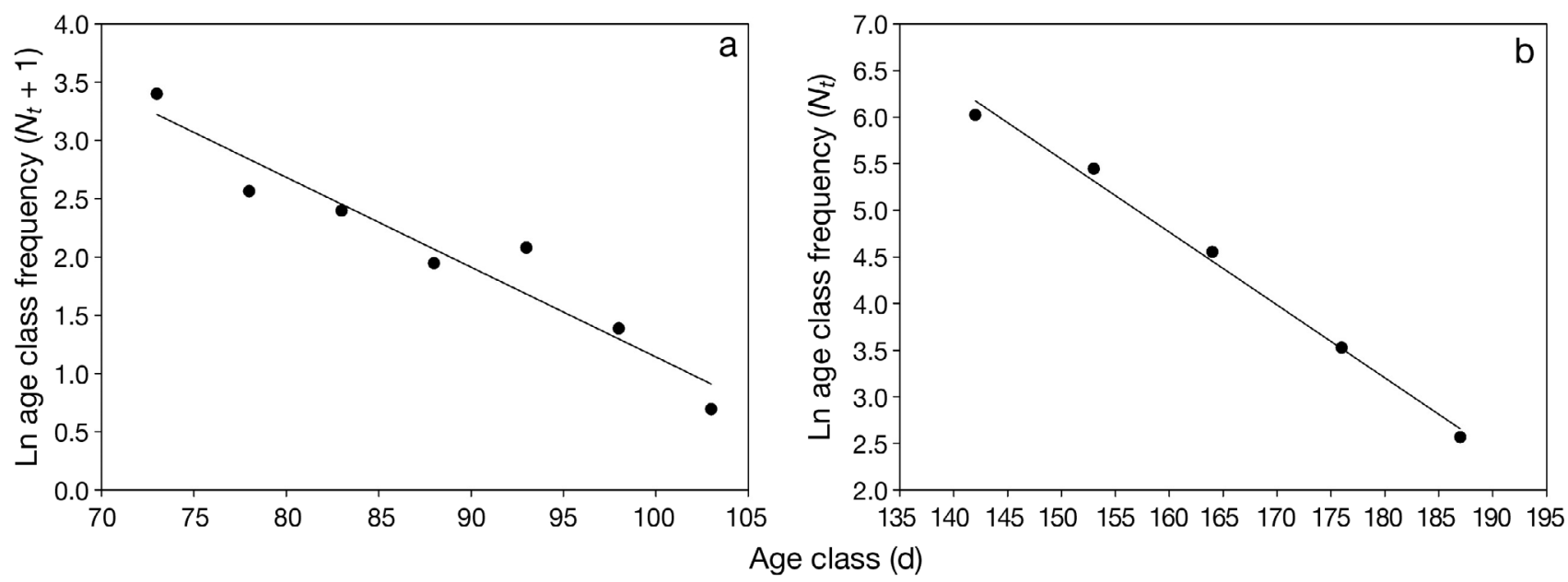

Fig. 5. (a) Catch curve of pelagic juvenile Baltic cod Gadus morhua. Natural log (Ln) of frequency per age class vs. age class (5 d bins). Linear regression equation: $y=-0.078 x+8.855 ; \mathrm{r}^{2}=0.925$. (b) Catch curve of demersal juvenile Baltic cod. Ln of frequency per age class vs. age class (11 d bins). Linear regression equation: $y=-0.078 x+17.291 ; r^{2}=0.993$. The slopes of the linear regressions provide estimates of the daily instantaneous mortality rate $(Z)$

\section{Mortality rates and back-calculated hatch dates of juveniles and seasonal egg abundance estimates}

Daily instantaneous mortality rates estimated by the age-based catch curve method were $Z=0.078$ for both the pelagic and the demersal juveniles (Fig. 5), corresponding to a percent mortality rate of $M=7.5 \% \mathrm{~d}^{-1}$. The sampled pelagic juveniles were hatched in the period from the end of July to the end of September 2000, i.e. Day 203 to 263 (Fig. 6). The demersal juveniles originated from the beginning of May to the beginning of August (Day 128 to 218). Abundance data of egg stage 1 from April, May, July, and August show an increase in spawning effort throughout the season (Fig. 6). Unfortunately, no ichthyoplankton sampling was conducted after August, when the highest egg abundances were found. However, results from a time series of ichthyoplankton data from the Bornholm Basin suggest that the sampling in August marked the abundance peak, and that spawning activity decreased remarkably shortly thereafter (Wieland et al. 2000, Kraus et al. 2012). To illustrate this, a schematic view of a typical seasonal egg production curve was added to Fig. 6.

\section{Comparison between simulated and observed distribution of pelagic juvenile cod}

The simulated residence probabilities of drifters after $70 \mathrm{~d}$ drift duration show that in the early spawning season 2000, the majority of drifters experienced a slight northward transport towards the Swedish coast (Fig. 7a). In mid-spawning season, drifters were largely retained on the spawning ground in the Bornholm Basin (Fig. 7b). Only in the late part of the spawning season were drifters advected into areas

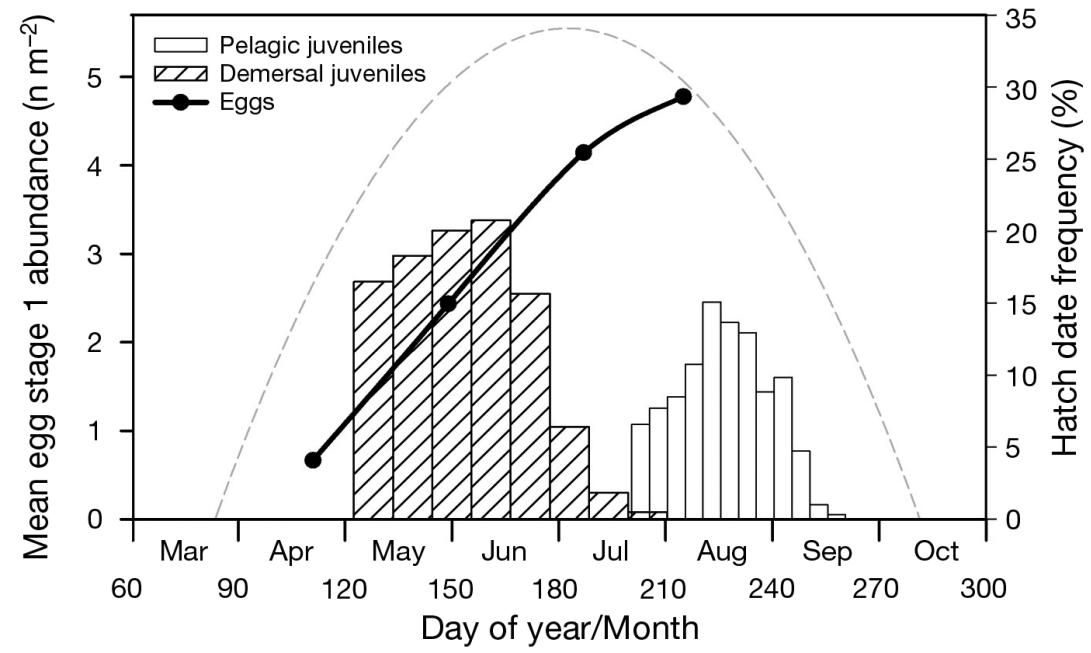

Fig. 6. Back-calculated, cumulative mortality corrected hatch date frequency distributions of pelagic (unfilled bars) and demersal (striped bars) juvenile Gadus morhua in relation to seasonal average egg stage 1 abundance (black dots) from ichthyoplankton surveys in the Bornholm Basin. Dashed grey line: schematic view of a typical seasonal egg-production curve of Baltic cod 


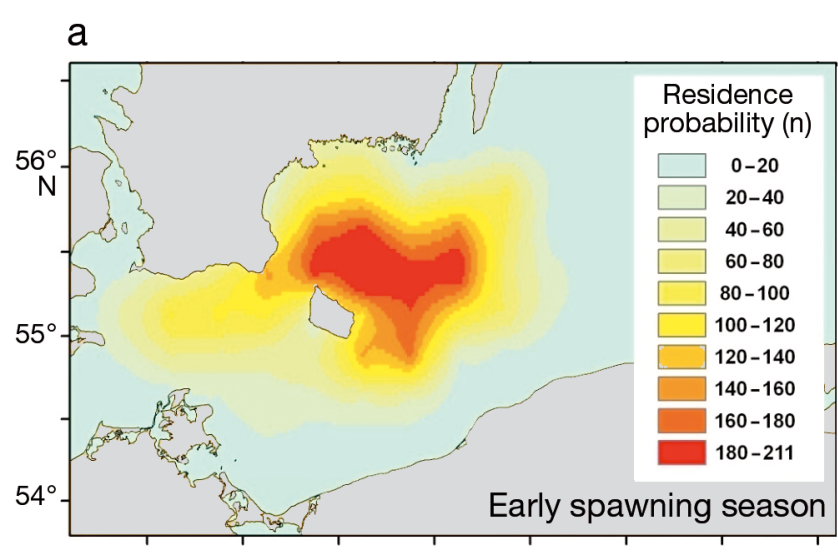

b

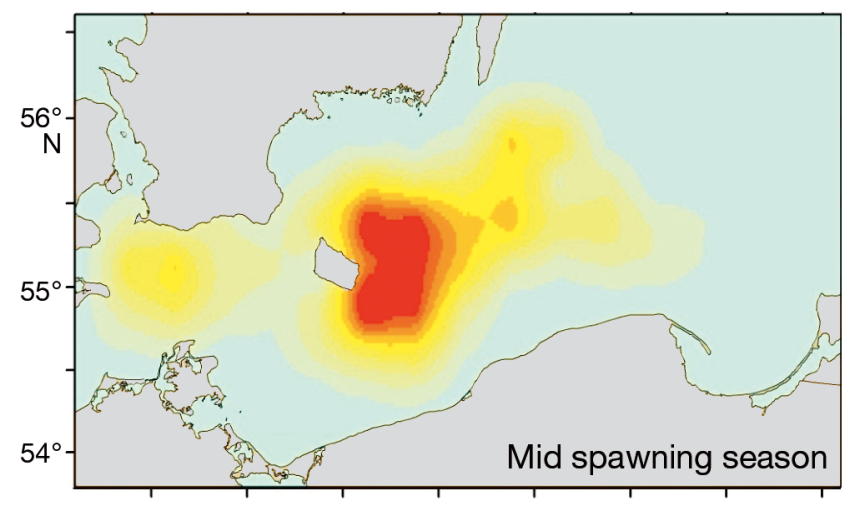

C

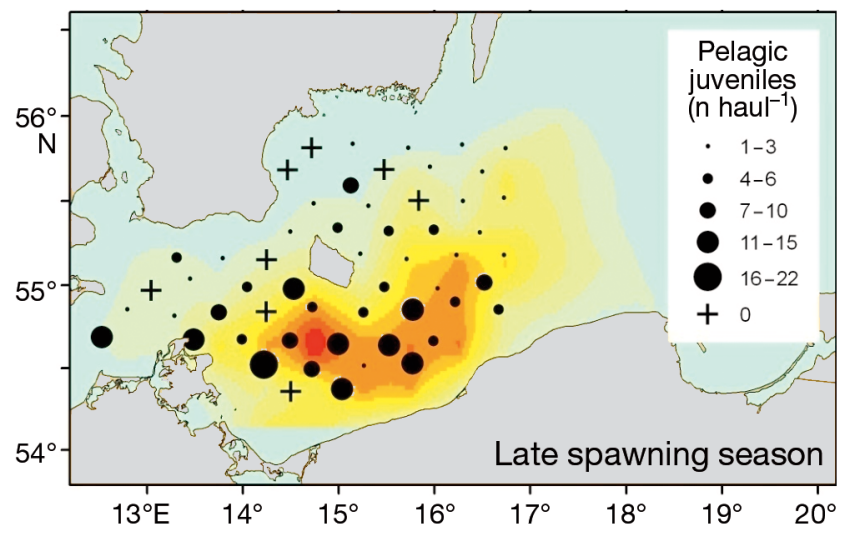

Fig. 7. Ability of the hydrodynamic model to simulate drift of larval and pelagic juvenile Baltic cod Gadus morhua. The color scale depicts the simulated residence probability of drifters released on the spawning ground in the Bornholm Basin throughout the spawning season in the year 2000 after $70 \mathrm{~d}$ of drift. Drifters released in (a) the early spawning season (1 April - 21 May), (b) the middle of the spawning season (31 May - 20 July), and (c) the late spawning season (30 July - 18 September), corresponding to the period of backcalculated hatch dates of pelagic juveniles, in comparison with the catch distribution of pelagic juveniles from the survey in November 2000 (black circles). A high coefficient of overlap (0.83) shows a good agreement between simulated and observed juvenile distributions for the late spawning season south and southwest of Bornholm. The late spawning season corresponds to the hatch period of pelagic juvenile survivors (25 July to 14 September) that were sampled during the survey in November. A high spatial overlap between simulated residence probabilities of drifters and the catch distribution of pelagic juveniles in the late spawning season is evident (Fig. 7c) and corroborated by a high overlap coefficient $C$ of 0.83 .

\section{Back-calculated hatch locations, egg distributions, RV, and OES probability}

The back-calculated survivor hatch locations were generally at the edges of the spawning area in the Bornholm Basin, while only a minor portion of fish had hatched in the central deep basin (Fig. 8a). Only $20 \%$ of survivors originated from the deepest central part of the basin where depths exceed $80 \mathrm{~m}$, while $80 \%$ had hatched in areas with depths shallower than $80 \mathrm{~m}$. Centers of survivor origin are located north and east of Bornholm and at the southeastern edge of the basin. A comparison of the observed survivor origin in the year 2000 (Fig. 8a) with the modeled average survival probability of cod larvae for a situation of low Pseudocalanus acuspes abundance (Fig. 8b, redrawn after Hinrichsen et al. 2002) shows a high degree of congruence. Especially apparent is the concurrence of high simulated survival probabilities with distinct centers of survivor origin in the northwestern regions of the spawning ground, north and east of Bornholm Island.

Fig. 8c,d shows the horizontal distribution of abundances of egg stages 1 and 4 in August 2000 in relation to the extent of the RV and the OES probability, respectively. Egg stage 1, as a proxy for spawning effort, is rather evenly distributed over the entire spawning ground, with slightly higher abundances in the northwestern part and at the southern and eastern edges. In contrast, the distribution of egg stage 4 shows very low abundances in the northwestern part of the area and higher abundances in the central, northeastern, and southeastern regions. The thickness of the RV has its largest extent in the southern and eastern parts of the basin, with high values of 15 to $23 \mathrm{~m}$ in the southern and intermediate values between 11 and $15 \mathrm{~m}$ in the northeastern areas (Fig. 8c). In contrast, the vertical extent of the reproductive volume in the northwestern area is considerably lower, ranging only from 1 to $9 \mathrm{~m}$. The OES shows a slightly different picture (Fig. 8d). Here, highest $(70 \%)$ and intermediate $(40 \%)$ values are 

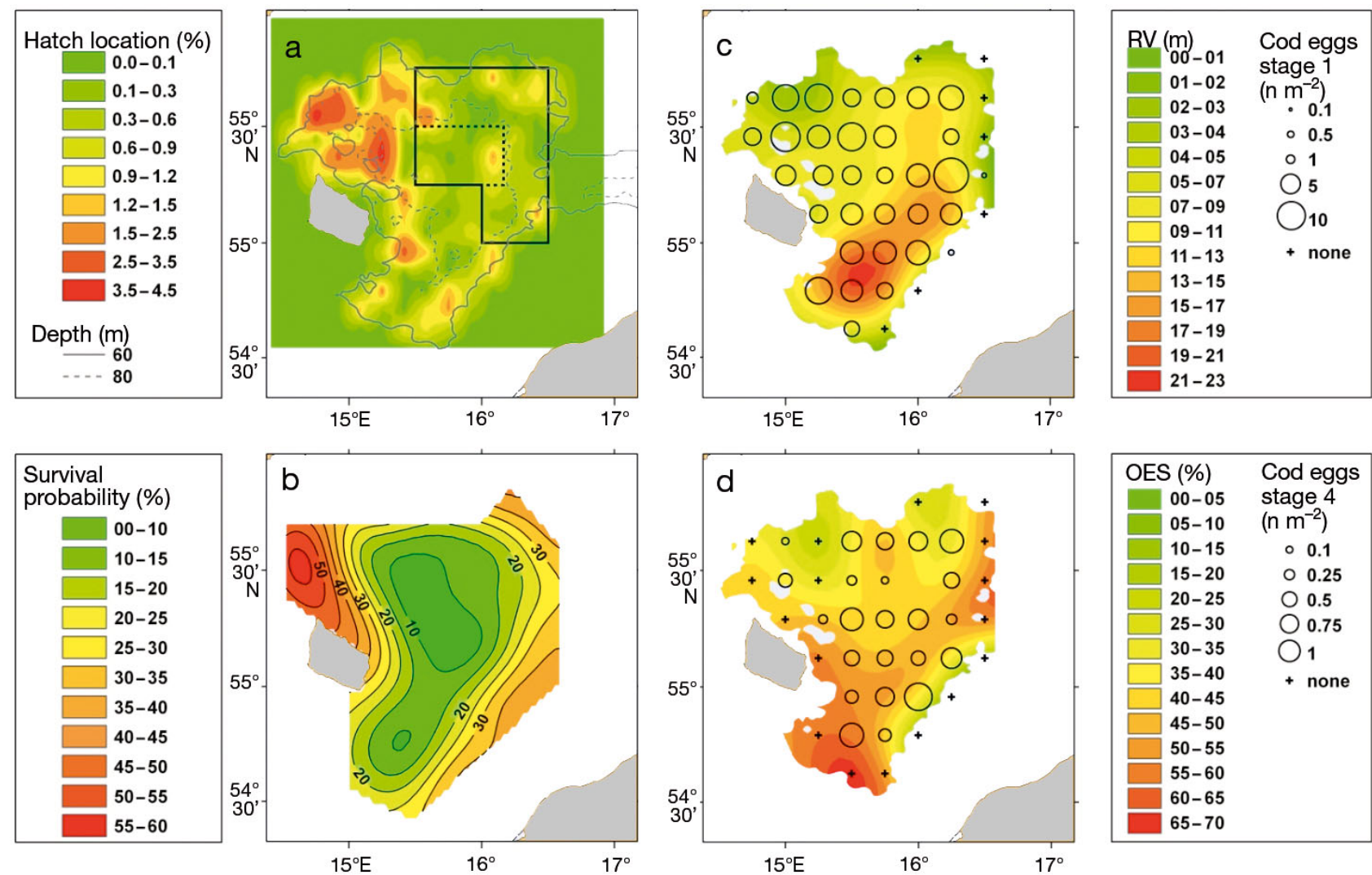

Fig. 8. Spawning activity and survival success of Baltic cod Gadus morhua early life stages in the Bornholm Basin. (a) Back-calculated hatch positions of pelagic juvenile survivors (color scale, \%) and location of a Marine Protected Area (black solid box: present extent; dashed box: extent in the year 2000). Thin grey lines: $60 \mathrm{~m}$ (solid) and $80 \mathrm{~m}$ (dashed) depth contours. (b) Modeled average survival probability (\%) of Baltic cod larvae in a situation simulating low abundances of Pseudocalanus acuspes nauplii (redrawn after Hinrichsen et al. 2002). (c) Thickness of the reproductive volume (RV; color scale, meters) and cod egg stage 1 distribution (circles, $\mathrm{n} \mathrm{m}^{-2}$ ) in August 2000. (d) Oxygen-related egg survival probability (OES; color scale, \%) and cod egg stage 4 distribution (circles, $\mathrm{n} \mathrm{m}^{-2}$ ) in August 2000

also found in the southern and eastern parts of the spawning area, respectively. However, in contrast to the RV, higher OES values also prevail at the northern and especially eastern coast of Bornholm. Lowest egg survival probabilities of only 20 to $35 \%$ are consistent with the RV as a proxy for egg survival found in the northwestern region.

\section{DISCUSSION}

\section{Hydrodynamic model suitability to track drift routes, and evaluation of estimated mortality rates}

The hydrodynamic model output was shown to correspond well with observed juvenile catch positions. Hence, there is a clear dependence of juvenile distribution on wind-induced drift, which is mainly controlled by the local atmospheric conditions over the
Baltic Sea. This is in accordance with earlier results reported by Hinrichsen et al. (2003a).

The mortality rates of $7.5 \% \mathrm{~d}^{-1}$ found for both pelagic and demersal juvenile cod in the present study are comparable to juvenile cod mortality rates reported from other areas. For Georges Bank cod, Mountain et al. (2008) estimated mortality rates between 5 and $10 \% \mathrm{~d}^{-1}$ for 50 to $60 \mathrm{~d}$ old fish, corresponding to sizes of ca. 1.5 to $2.5 \mathrm{~cm}$ depending on the month of capture. For the same area, Serchuk et al. (1994) estimated the level of post-larval mortality for Georges Bank cod to be $7.8 \% \mathrm{~d}^{-1}$, and Lough (2010) estimated the mortality rates of recently settled juveniles to be ca. 3 to $8 \% \mathrm{~d}^{-1}$ and the mortality from the pelagic juvenile stage $(20-50 \mathrm{~mm})$ to the 1 -group to be ca. 3 to $5 \% \mathrm{~d}^{-1}$. From midwater trawl surveys for northeast Arctic cod, Sundby et al. (1989) provided mortality rates from the early juvenile stage (2-3 mo post hatch, $20-50 \mathrm{~mm}$ ) to the 0 -group stage 
(4-5 mo, 60-80 mm) ranging from 1 to $4 \% \mathrm{~d}^{-1}$. Thus, the mortality rates estimated for juvenile cod in the present study seem to be reasonable.

\section{Spatio-temporal origin of juvenile survivors and relation to recruitment}

The patterns of spatio-temporal survivor origin found in the present study are in good agreement with previous modeling studies and with spatiotemporal abundance patterns of suitable prey for early larval stages, which may provide support for the critical period and match-mismatch hypotheses.

For the Baltic cod stock, Vallin et al. (1999) reviewed potential factors that influence reproductive success. The impact of environmental conditions on egg fertilization and survival, egg predation by clupeids, and decreased larval viability at low oxygen concentrations have been identified as sources of early life stage mortality, while predation on larvae appears to have only limited impact on reproductive success, mainly because of a limited vertical overlap between larvae and predators such as sprat, herring, and gelatinous plankton (Köster et al. 2005, Schaber et al. 2011). In addition, egg quality and fecundity as influenced by (1) fishery-induced changes in the age structure of the stock (Vallin \& Nissling 2000), (2) food availability for adults during maturation (Kraus et al. 2002), and (3) parental effects (Nissling et al. 1998, Vallin \& Nissling 2000, Trippel et al. 2005), as well as impacts of pollution and environmental conditions on malformation of eggs and larvae (Vallin et al. 1999), have been suggested to influence reproductive success, although evidence is inconclusive, especially for the latter factor. However, production of surviving eggs and larval abundance are not correlated in Baltic cod, whereas larval abundance is significantly related to year-class strength as estimated from multispecies models, indicating that the early larval stage may be the most critical period determining recruitment success (Köster et al. 2003).

Modeling studies have suggested that the degree of dispersal of larvae from the main spawning area is a key process influencing recruitment success of the stock (Voss et al. 1999, Hinrichsen et al. 2001). The suggested process influencing larval survival is transport of larvae and pelagic juveniles to coastal nursery habitats with better food supply during periods of high wind stress and retention in the central basin with less suitable food supply during periods of low wind stress of variable wind direction. Larval Baltic cod mainly prey on nauplii of the abundant calanoid copepods Pseudocalanus acuspes, Temora longicornis and Acartia spp. in the area. According to modeling studies by Hinrichsen et al. (2002, 2003b, 2005), food limitation for first-feeding cod larvae during the last 2 decades was caused by a pronounced decline of P. acuspes (Möllmann et al. 2000), which is the preferred prey of larval Baltic cod (Voss et al. 2003). At low abundances of this copepod, first-feeding larvae only had higher survival probability in the early spawning season or in the late spawning season when they hatched on the outer edges of the Bornholm Basin or were rapidly transported towards shallower areas (Hinrichsen et al. 2002). In contrast, larvae hatched within the center of the Bornholm Basin did not encounter sufficient prey for survival along their drift routes.

These previous modeling results agree well with the findings of the present field study. Pelagic and demersal juvenile survivors originated from May to September, i.e. from the entire spawning season, largely following the seasonal development in spawning intensity. However, a 'gap' between hatch date distributions of pelagic and demersal juveniles was found during summer. This gap may partly be a consequence of variable catchability for different size classes by the gears used, which may especially affect abundance estimates of newly settled juveniles in the length range of 4 to $7 \mathrm{~cm}$ (Hüssy et al. 1997, ICES 2013). Furthermore, ages and spawning dates of demersal juveniles were estimated from a published age-length relationship which was established for demersal juveniles from the year classes 1990 to 1992 (Fey \& Linkowski 2006), but juveniles in the present study were caught in 2000 and may have experienced different growth conditions resulting in different growth trajectories. If juveniles in the present study expressed lower growth rates, this would result in earlier hatch dates and an even larger gap in the hatch date distribution of pelagic and demersal juveniles, while higher growth rates would lead to a smaller gap. However, length frequency distributions of juveniles from the year classes 1990 to 1992 and 2000 were very similar (for details, see the Supplement at www.int-res.com/articles/suppl/m511p165_ supp.pdf), indicating that juveniles from both periods experienced similar growth conditions and that the application of the published age-length relationship provides a reasonable estimate of demersal juvenile ages in the present study. Finally, due to the fact that pelagic and demersal juveniles were caught with different gears having different catchability, the relative importance of early and late survivors for the strength of the year class could not be quantified. 
Despite these shortcomings, the observed gap indicates lower survival during a time window at peak spawning, lasting from the end of June to the beginning of August (Day 170 to 220). Decreased survival during summer was also suggested by an earlier study (Hinrichsen et al. 2003a) which showed a similar gap in the birthdate distribution of demersal Baltic cod lasting from mid-May to mid-July. Windows of higher survival in the early and late spawning season of Baltic cod are also in accordance with results from a bio-physical modeling study which simulated low abundances of $P$. acuspes (Hinrichsen et al. 2002), even though the model suggested a more extended window of lower survival from mid-May to the end of August.

Lower larval survival during summer may be related to the availability of suitable prey, especially for first-feeding larvae. Unfortunately, no information on larval prey availability is available for 2000, the year of our study. However, detailed information on stage-resolved, seasonal abundance dynamics of the main larval cod prey species has recently become available for 2002/2003 (Renz \& Hirche 2006, Dutz et al. 2010, Peters et al. 2013), i.e. shortly after the year of our study. Nauplii of $P$. acuspes show an abundance maximum in spring, mainly in April and May, followed by a rapid decline and very low abundances during the remainder of the year (Renz \& Hirche 2006). Nauplii of T. longicornis and Acartia spp. also show abundance peaks during spring followed by a sharp decline towards summer, but in contrast to $P$. acuspes, abundance peaks are also found during late summer and fall (Dutz et al. 2010, Peters et al. 2013). Thus, the gap in the hatch date distribution of juvenile Baltic cod survivors may have coincided with a period of low nauplii abundances of all 3 species, while the early and late hatched survivors originate from periods which may have provided high nauplii abundances of all 3 species and of T. longicornis and Acartia spp., respectively. In addition, first-feeding larvae of Baltic cod need to migrate from hatching depths $(>50 \mathrm{~m})$ to upper water layers, as they can only find sufficient abundances of nauplii in these layers, but higher temperatures in upper layers probably lead to high energy demands and thermal stress which will likely result in high mortalities (Huwer et al. 2011). As surface temperatures in the Bornholm Basin reach a maximum during summer, this probably has an additional negative influence on the survival probability of larvae hatched in the middle of the spawning season.

Distinct 'windows of survival' have been found to be of importance for the recruitment process of other species (e.g. Limburg 2001, Lapolla \& Buckley 2005, Baumann et al. 2008), and the timing of spawning in relation to the availability of suitable prey, especially for first-feeding larvae, may likewise have a large influence on the recruitment of Baltic cod. However, the phenology of prey species may show relatively large variability, as there are e.g. indications for a strong variability in spring timing of $T$. longicornis (Dutz et al. 2010). Further studies are needed to establish more direct links between the seasonal dynamics of prey availability and larval growth, survival, and recruitment of Baltic cod.

Concerning the spatial origin of survivors, the finding that the vast majority of pelagic juveniles originated from areas at the edges of the Bornholm Basin, while only a small part had hatched in the Basin center, is also in good agreement with previous modeling results (cf. Fig. 8a,b) and provides field-based evidence that the bio-physical model from Hinrichsen et al. (2002) is capable of realistically simulating individual larval survival probability. Like the temporal patterns of survivor origin, the observed spatial pattern is also likely related to spatio-temporal differences in the availability of copepod nauplii for earlystage larvae. The geographical distribution of $P$. acuspes nauplii in the central Baltic is associated with the distribution of adults, preferring higher salinities (Möllmann et al. 2000) encountered in deeper parts of the area. T. longicornis and Acartia spp., not confined to high salinities, but to warmer waters (Möllmann et al. 2000), are generally found in the upper $50 \mathrm{~m}$ of the water column and are distributed in more shallow regions. This implies high concentrations of $P$. acuspes nauplii early in the cod spawning season in central spawning areas with sufficient salinity and higher nauplii production of $T$. longicornis and Acartia spp. at the basin edges in the late spawning season, where the back-tracked pelagic juveniles were born.

In principle, higher numbers of juveniles originating from the edges of the basin could also simply be related to an increased spawning activity in these areas. However, this possibility can be ruled out, as evidenced by the egg abundance data. Egg stage 1, as a proxy for spawning effort, was relatively evenly distributed over the entire spawning ground. The abundance of stage 4 eggs, i.e. the stage immediately before hatching in the Baltic (Wieland et al. 1994), was lowest in the northwestern basin. While this decrease in abundance from stage 1 to 4 corresponds well to the spatial distribution of oxygen-dependent egg survival probabilities (RV and OES) it does not match with juvenile hatch locations. Thus, the spatial 
mismatch between production of surviving eggs and survivor origins provides evidence that larval mortality is an important recruitment process in Baltic cod.

In summary, most favorable feeding conditions for first-feeding larvae seem to occur in the early spawning season, while decreasing availability of nauplii in the middle of the spawning season may reduce larval survival, whereas later hatched larvae may profit from increasing abundances of nauplii of $T$. longicornis and Acartia spp., but only if they are hatched in or rapidly transported to shallower coastal areas. Even though it was not possible in our study to directly relate larval survival with prey abundances, the high agreement in patterns of spatio-temporal survivor origin from the present observation with previous model results and the spatio-temporal distribution of major larval cod prey species may provide empirical support for the importance of larval survival in the recruitment process of Baltic cod, in particular with relation to Hjort's (1914) critical period and Cushing's (1975) match-mismatch hypotheses.

To further elucidate the importance of spatio-temporal origin for the fate of a year class of Baltic cod, high-frequency, quantitative sampling of consecutive developmental stages and their prey, both in space and time, seems mandatory to be able to follow different sub-cohorts from the egg to at least the juvenile stage. Such an approach has been exemplified in a number of studies on a variety of species (e.g. Meekan \& Fortier 1996, Lapolla \& Buckley 2005, Irigoien et al. 2008), even though they usually did not have to cope with such extensive spawning seasons as in Baltic cod.

\section{Evaluation of the presently enforced MPA in the Bornholm Basin}

The approach of back-calculating the spatial origin of survivors as presented herein can be applied to evaluate the location of MPAs with respect to facilitating undisturbed, successful spawning. As shown in Fig. 8a, only few juvenile survivors $(22.5 \%)$ originated from the presently enforced MPA in the Bornholm Basin, and very few $(5.3 \%)$ from the central part which was protected in 2000 , i.e. at the time when fish used in the present analysis were collected. In an environmental situation characterized by stagnation as encountered in 2000, both the smaller and the extended MPAs in the Bornholm Basin seem to have a low potential to effectively enhance the Baltic cod stock through protection of spawning ag- gregations contributing most to the recruitment success. Offspring with high survival probability are actually not spawned in the protected area. Instead, locations outside the MPA, especially in the northwestern part of the Bornholm Basin, seem to yield the highest probability for enhanced survival of larvae and, eventually, subsequent recruitment. However, our results only cover $1 \mathrm{yr}$, and additional years need to be included in this evaluation to determine whether the observed spatial survival patterns are stable or vary between years, due to variable environmental forcing conditions, e.g. after inflow situations. Apart from this, it is our opinion that this type of analysis provides a valuable tool for the evaluation of the performance of MPAs designed to secure undisturbed spawning and to promote recruitment of marine fish stocks.

\section{Utility of the characteristics-of-survivors approach to study recruitment and conclusions}

Recruitment success in marine fish is mainly determined through variable mortality during early life, but reliable mortality estimates from field sampling are difficult to obtain (Houde 1987). In contrast, the analysis of survivor characteristics has the advantage of analyzing fish that have already proven to be the successful ones of a year class, and thus provides important indications for possible factors influencing the recruitment process in fish populations. In fact, Limburg et al. (1999) stated that they probably would have drawn erroneous conclusions about the recruitment potential of different cohorts, had they not included a retrospective analysis based on the characteristics of survivors. By applying survivor analysis to field samples of Baltic cod, we found empirical evidence for the importance of food availability during the larval stage in shaping recruitment dynamics, as suggested by previous results from time-series analysis (Köster et al. 2003), bio-physical modeling (Hinrichsen et al. 2002), and larval growth performance based on RNA:DNA ratios (Huwer et al. 2011).

Recruitment is routinely estimated for most commercially important fish stocks. However, in most stocks the underlying mechanisms determining recruitment variability are still poorly understood and are usually limited to general concepts such as food availability or relations with other environmental factors (Cowan \& Shaw 2002). Especially processes operating with high spatial variability are normally poorly resolved (Irigoien et al. 2008). Our study is the first to provide empirical evidence for spatial differ- 
ences in larval survival of Baltic cod from field samples. From the results, we conclude that addressing spatio-temporal variability in survival of early life stages has a high potential to improve our understanding of acting and interacting processes affecting recruitment and to construct environmentally sensitive stock-recruitment models. Moreover, such dynamics need to be considered in spatial and temporal management measures (Eero et al. 2012), e.g. the design of protected seasons and areas. Larvalstage processes seem to have the potential to introduce major variability in the recruitment levels of Baltic cod, but further studies are needed to assess their relative importance in relation to other processes (Huwer et al. 2011). Considering the extremely protracted spawning season of Baltic cod, such studies should ideally combine the characteristics-ofsurvivors approach with high-resolution field sampling in both time and space, aiming to investigate the seasonal variability in spawning and larval emergence in relation to the phenology of zooplankton prey (e.g. Dutz et al. 2010) and the resulting implications for larval prey preferences, condition, growth, and survival.

Acknowledgements. We acknowledge the help of all the people involved in field sampling onboard RVs 'Alkor' and 'Solea.' This work is a contribution to the BONUS project BIO-C3. This study was supported by a grant to B.H. (PhD grant number WP6-SYSBS-1048) from the European Network of Excellence for Ocean Ecosystem Analysis (EUROCEANS, FP 6 NoE 511106-2) and by the SLIP research school under the Danish Network for Fisheries and Aquaculture Research (FISHNET) financed by the Danish Ministry for Food, Agriculture, and Fisheries and the Danish Council for Independent Research, Technology, and Production Sciences. This work was partly funded by the International Femern Belt Science Provision Project and by the EU FP7 framework project VECTORS (grant no. 266445). We thank the editor and the anonymous reviewers for their constructive comments, which helped to improve an earlier version of the manuscript.

\section{LITERATURE CITED}

Baumann H, Voss R, Hinrichsen HH, Mohrholz V, Schmidt JO, Temming A (2008) Investigating the selective survival of summer- over spring-born sprat, Sprattus sprattus, in the Baltic Sea. Fish Res 91:1-14

Bergstroem S, Carlsson B (1994) River runoff to the Baltic Sea: 1950-1990. Ambio 23:280-287

> Campana SE (1989) Otolith microstructure of three larval gadids in the Gulf of Maine, with inferences on early life history. Can J Zool 67:1401-1410

> Clemmesen C, Doan T (1996) Does otolith structure reflect the nutritional condition of a fish larva? Comparison of otolith structure and biochemical index (RNA/DNA ratio) determined on cod larvae. Mar Ecol Prog Ser 138:33-39
Cowan JH Jr, Shaw RF (2002) Recruitment. In: Fuiman LA, Werner RG (eds) Fishery science. The unique contributions of early life stages. Blackwell Science, Malden, MA, p 88-111

Cushing DH (1975) Marine ecology and fisheries. Cambridge University Press, London

> Dutz J, Mohrholz V, van Beusekom JEE (2010) Life cycle and spring phenology of Temora longicornis in the Baltic Sea. Mar Ecol Prog Ser 406:223-238

Eero M, Vinther M, Haslob H, Huwer B, Casini M, StorrPaulsen M, Köster F (2012) Spatial management of marine resources can enhance the recovery of predators and avoid local depletion of forage fish. Conserv Lett 5: 486-492

Fey DP, Linkowski TB (2006) Predicting juvenile Baltic cod (Gadus morhua) age from body and otolith size measurements. ICES J Mar Sci 63:1045-1052

> Gallego A, North EW, Petitgas P (2007) Introduction: status and future of modelling physical-biological interactions during the early life of fishes. Mar Ecol Prog Ser 347: 121-126

Grønkjær P, Schytte M (1999) Non-random mortality of Baltic cod larvae inferred from otolith hatch-check sizes. Mar Ecol Prog Ser 181:53-59

- Grønkjær P, Wieland K (1997) Ontogenetic and environmental effects on vertical distribution of cod larvae in the Bornholm Basin, Baltic Sea. Mar Ecol Prog Ser 154: 91-105

Grønkjær P, Clemmesen C, St John MA (1997) Nutritional condition and vertical distribution of Baltic cod larvae. J Fish Biol 51:352-369

Hinrichsen HH, Lehmann A, St John MA, Bruegge B (1997) Modeling the cod larvae drift in the Bornholm Basin in summer 1994. Cont Shelf Res 17:1765-1784

> Hinrichsen HH, St John MA, Aro E, Grønkjær P, Voss R (2001) Testing the larval drift hypothesis in the Baltic Sea: retention versus dispersion caused by wind-driven circulation. ICES J Mar Sci 58:973-984

> Hinrichsen HH, Möllmann C, Voss R, Köster FW, Kornilovs G (2002) Biophysical modeling of larval Baltic cod (Gadus morhua) growth and survival. Can J Fish Aquat Sci 59:1858-1873

Hinrichsen HH, Böttcher U, Köster FW, Lehmann A, St John MA (2003a) Modelling the influences of atmospheric forcing conditions on Baltic cod early life stages: distribution and drift. J Sea Res 49:187-201

> Hinrichsen $\mathrm{HH}$, Lehmann A, Möllmann C, Schmidt JO (2003b) Dependency of larval fish survival on retention/ dispersion in food limited environments: the Baltic Sea as a case study. Fish Oceanogr 12:425-433

> Hinrichsen HH, Schmidt JO, Petereit C, Möllmann C (2005) Survival probability of Baltic larval cod in relation to spatial overlap patterns with their prey obtained from drift model studies. ICES J Mar Sci 62:878-885

Hinrichsen HH, Voss R, Wieland K, Köster F, Andersen KH, Margonski P (2007) Spatial and temporal heterogeneity of the cod spawning environment in the Bornholm Basin, Baltic Sea. Mar Ecol Prog Ser 345:245-254

Hjort J (1914) Fluctuations in the great fisheries of northern Europe viewed in the light of biological research. Rapp P-V Reun Cons Int Expt Mer 20:1-228

Horn HS (1966) Measurement of overlap in comparative ecological studies. Am Nat 100:419-424

Houde ED (1987) Fish early life dynamics and recruitment variability. Am Fish Soc Symp 2:17-29 
Hüssy K, St. John MA, Böttcher U (1997) Food resource utilization by juvenile Baltic cod Gadus morhua: a mechanism potentially influencing recruitment success at the demersal juvenile stage? Mar Ecol Prog Ser 155:199-208

> Huwer B, Clemmesen C, Grønkjær P, Köster FW (2011) Vertical distribution and growth performance of Baltic cod larvae - field evidence for starvation-induced recruitment regulation during the larval stage? Prog Oceanogr 91:382-396

ICES (International Council for the Exploration of the Sea) (2004) Report of the study group on closed spawning areas of eastern Baltic Cod (SGCSA). Charlottenlund, 9-12 March 2004. ICES CM 2004/ACFM:17. ICES, Copenhagen

ICES (2013) Report of the Baltic Fisheries Assessment Working Group. Copenhagen, 10-17 April 2013. ICES CM 2013/ACOM:10. ICES, Copenhagen

> Irigoien X, Cotano U, Boyra G, Santos M, Alvarez P, Ibaibarriaga $L$ (2008) From egg to juvenile in the Bay of Biscay: spatial patterns of anchovy (Engraulis encrasicolus) recruitment in a non-upwelling region. Fish Oceanogr $17: 446-462$

Killworth PD, Stainforth D, Webbs DJ, Paterson SM (1991) The development of a free-surface Bryan-Cox-Semtner ocean model. J Phys Oceanogr 21:1333-1348

> Köster FW, Hinrichsen HH, St. John MA, Schnack D, MacKenzie BR, Tomkiewicz J, Plikshs M (2001) Developing Baltic cod recruitment models. II. Incorporation of environmental variability and species interaction. Can J Fish Aquat Sci 58:1534-1556

- Köster FW, Hinrichsen HH, Schnack D, St John MA and others (2003) Recruitment of Baltic cod and sprat stocks: identification of critical life stages and incorporation of environmental variability into stock-recruitment relationships. Sci Mar 67:129-154

Köster FW, Möllmann C, Hinrichsen HH, Wieland K and others (2005) Baltic cod recruitment - the impact of climate variability on key processes. ICES J Mar Sci 62: 1408-1425

> Kraus G, Tomkiewicz J, Köster FW (2002) Egg production of Baltic cod (Gadus morhua) in relation to variable sex ratio, maturity, and fecundity. Can J Fish Aquat Sci 59: 1908-1920

Kraus G, Hinrichsen HH, Voss R, Teschner E, Tomkiewicz J, Köster FW (2012) Robustness of egg production methods as a fishery independent alternative to assess the Eastern Baltic cod stock (Gadus morhua callarias L.). Fish Res 117-118:75-85

> Lapolla A, Buckley LJ (2005) Hatch date distributions of young-of-year haddock Melanogrammus aeglefinus in the Gulf of Maine/ Georges Bank region: implications for recruitment. Mar Ecol Prog Ser 290:239-249

> Lehmann A (1995) A three-dimensional baroclinic eddyresolving model of the Baltic Sea. Tellus A Dynam Meteorol Oceanogr 47:1013-1031

Lehmann A, Hinrichsen HH (2000a) On the wind driven and thermohaline circulation of the Baltic Sea. Phys Chem Earth B Hydrol Oceans Atmos 25:183-189

- Lehmann A, Hinrichsen HH (2000b) On the thermohaline variability of the Baltic Sea. J Mar Syst 25:333-357

> Lehmann A, Krauss W, Hinrichsen HH (2002) Effects of remote and local atmospheric forcing on circulation and upwelling in the Baltic Sea. Tellus A Dynam Meteorol Oceanogr 54:299-316

> Limburg KE (2001) Through the gauntlet again: demo- graphic restructuring of American shad by migration. Ecology 82:1584-1596

Limburg KE, Pace ML, Arend KK (1999) Growth, mortality, and recruitment of larval Morone spp. in relation to food availability and temperature in the Hudson River. Fish Bull 97:80-91

Lough RG (2010) Juvenile cod (Gadus morhua) mortality and the importance of bottom sediment type to recruitment on Georges Bank. Fish Oceanogr 19:159-181

Marteinsdottir G, Gunnarsson B, Suthers IM (2000) Spatial variation in hatch date distributions and origin of pelagic juvenile cod in Icelandic waters. ICES J Mar Sci 57: 1182-1195

> Meekan MG, Fortier L (1996) Selection for fast growth during the larval life of Atlantic cod Gadus morhua on the Scotian shelf. Mar Ecol Prog Ser 137:25-37

Möllmann C, Kornilovs G, Sidrevics L (2000) Long-term dynamics of main mesozooplankton species in the central Baltic Sea. J Plankton Res 22:2015-2038

Mountain D, Green J, Sibunka J, Johnson D (2008) Growth and mortality of Atlantic cod Gadus morhua and haddock Melanogrammus aeglefinus eggs and larvae on Georges Bank, 1995 to 1999. Mar Ecol Prog Ser 353: 225-242

> Nielsen R, Munk P (2004) Growth pattern and growth dependent mortality of larval and pelagic juvenile North Sea cod Gadus morhua. Mar Ecol Prog Ser 278:261-270

- Nissling A, Larsson R, Vallin L, Frohlund K (1998) Assessment of egg and larval viability in cod, Gadus morhua: methods and results from a experimental study. Fish Res 38:169-186

> Petereit C, Hinrichsen HH, Franke A, Köster FW (2014) Floating along buoyancy levels: dispersal and survival of western Baltic fish eggs. Prog Oceanogr 122:131-152

> Peters J, Dutz J, Hagen W (2013) Trophodynamics and lifecycle strategies of the copepods Temora longicornis and Acartia longiremis in the Central Baltic Sea. J Plankton Res 35:595-609

Plikshs M, Kalejs M, Grauman G (1993) The influence of environmental conditions and spawning stock size on the year-class strength of the eastern Baltic cod. ICES CM 1993/J:22. ICES, Copenhagen

Renz J, Hirche HJ (2006) Life cycle of Pseudocalanus acuspes Giesbrecht (Copepoda, Calanoida) in the Central Baltic Sea: I. Seasonal and spatial distribution. Mar Biol 148:567-580

Rice JA, Crowder LB, Holey ME (1987) Exploration of mechanisms regulating larval survival in Lake Michigan bloater: a recruitment analysis based on characteristics of individual larvae. Trans Am Fish Soc 116:703-718

Ricker WE (1975) Computation and interpretation of biological statistics of fish populations. Bull Fish Res Board Can 191:1-382

Rohlf N (1999) Aktivität und Vertikalwanderung der Larven des Ostseedorsches (Gadus morhua callaris) während der Dottersackphase. PhD thesis, Christian-AlbrechtsUniversität, Kiel

Schaber M, Haslob H, Huwer B, Harjes A and others (2011) Spatio-temporal overlap of the alien invasive ctenophore Mnemiopsis leidyi and ichthyoplankton in the Bornholm Basin (Baltic Sea). Biol Invasions 13:2647-2660

Schmidt JO, Hinrichsen HH (2008) Impact of prey field variability on early cod Gadus morhua larval survival: a sensitivity study of a Baltic cod individual-based model. Oceanologia 50:205-220 
Serchuk FM, Grosslein MD, Lough RG, Mountain DG (1994) Fishery and environmental factors affecting trends and fluctuations in the Georges Bank and Gulf of Maine Atlantic cod stocks: an overview. ICES Mar Sci Symp 198:77-109

Sundby S, Bjørke H, Soldal AV, Olsen S (1989) Mortality rates during the early life stages and year-class strength of the North-East Arctic cod (Gadus morhua L.). Rapp P-V Reun Cons Int Expl Mer 191:351-358

Taggart CT, Frank KT (1990) Perspectives on larval fish ecology and recruitment processes: probing the scales of relationships. In: Sherman K, Alexander LM, Gold BD (eds) Large marine ecosystems: patterns, processes and yields. American Association for the Advancement of Science, Washington, DC, p 151-164

Trippel EA, Kraus G, Köster FW (2005) Maternal and paternal influences on early life history traits and processes of Baltic cod Gadus morhua. Mar Ecol Prog Ser 303: 259-267

Vallin L, Nissling A (2000) Maternal effects on egg size and egg buoyancy of Baltic cod, Gadus morhua-implications for stock structure effects on recruitment. Fish Res 49:21-37

Vallin L, Nissling A, Westin L (1999) Potential factors in-

Editorial responsibility: Alejandro Gallego,

Aberdeen, UK fluencing reproductive success of Baltic cod, Gadus morhua: a review. Ambio 28:92-99

Voss R, Hinrichsen HH, St John MA (1999) Variations in the drift of larval cod (Gadus morhua L.) in the Baltic Sea: combining field observations and modelling. Fish Oceanogr 8:199-211

> Voss R, Hinrichsen HH, Wieland K (2001) Model-supported estimation of mortality rates in Baltic cod (Gadus morhua callarias L.) larvae: the varying impact of 'critical periods'. BMC Ecol 1:4

Voss R, Köster FW, Dickmann M (2003) Comparing the feeding habits of co-occurring sprat (Sprattus sprattus) and cod (Gadus morhua) larvae in the Bornholm Basin, Baltic Sea. Fish Res 63:97-111

Wieland K, Jarre-Teichmann A (1997) Prediction of vertical distribution and ambient development temperature of Baltic cod, Gadus morhua L., eggs. Fish Oceanogr 6:172-187

Wieland K, Waller U, Schnack D (1994) Development of Baltic cod eggs at different levels of temperature and oxygen content. Dana 10:163-177

- Wieland K, Jarre-Teichmann A, Horbowa K (2000) Changes in the timing of spawning of Baltic cod: possible causes and implications for recruitment. ICES J Mar Sci 57: 452-464

Submitted: January 22, 2014; Accepted: May 20, 2014 Proofs received from author(s): August 19, 2014 